\title{
ONE AMERICAN EDUCATORS' SENSITIVITY TO MONGOLIA
}

\section{Candace Kaye}

\section{Background}

I have been invited by Dr.Tsedendambyn Batbayar, Editor of the Mongolian Journal of International Affairs, to read and respond to Dr. George H.Quester's insightful paper, American Sensitivity to Mongolia, published in The Mongolian Journal of International Affairs(pp. 68-76, vol. 3, 1996). Dr. Quester is Professor of Government Politics at the University of Maryland, where he teaches courses on defence policy and arms control and U.S. foreign policy. In his article, Dr.Quester examines ties between America and China, America and Mongolia and future policy possibilities. His main thesis is that very few Americans know Mongolia and that this lack of knowledge may cause future problems "for the national interests of both countries (p. 68)". His concern is that, since most Americans have greater knowledge and more positive regard for China, this tie can be a concern for Mongolians, "a country of two million people resting next to 1200 million Chinese (p. 68)" and result in a choice of support for China rather than Mongolia when questions of policy decisions occur.

In the following discussion, I shall present my own perspective, both as an educator interested in international and comparative studies of education and as an American fascinated by the country and people of Mongolia.

\section{Perceptions versus Understanding}

I became actively involved with the new Mongolia in 1992 in my position as liaison between the United States Information Service in Beijing and Ulaanbaatar. Prior to that experience, the sensory images that would come to mind when I considered Mongolia included:

- the visual beauty of the vast countryside as portrayed in the National Geographic Magazine

- the feel of the cashmere that, according to the label, came from that country the delicious taste of Mongolian barbecue served in a favorite San Antonio, Texas restaurant, and also,

- The antigun consideration of whether ancient Mongolians had indeed walked across the land bridge and had become known as "Native Americans". 
- An ongoing question beginning in childhood with how the Great Wall, Genghis Khan, and China became historically connected; knowing always that the connection was definitive and important.

Dr. Quested observes that "the typical American has had much stronger positive feelings, over the past century and longer, and somewhat greater knowledge (in that regard, I must admit that I am typical), about China ". However, in my own original naive understanding of Mongolia, I never thought of China as being more or less important than Mongolia; nor, actually, did I ever have contemporary political considerations of their hierarchy. These two countries were always two separate entities to me and this thinking led me to consider a profile of national equity for both. My thinking went something like, "These are two very strong countries, who over many hundred of years have attempted to overpower one another".

I have found that after four years of associating myself with some intensity in the new Mongolia and its energetic, in fact passionate, interest in selfdevelopment, academics and nonacademic in the United States continue to have only the vaguest understanding of this new Mongolia and its connections to its neighbors. Additionally, I have found that knowledge of the history or contemporary society of this fascinating country is even as simple as my own original understanding, if that much.

I find today that when mentioning Mongolia to other Americans that the biggest surprise to them is the new democratic government. From this reaction, I have concluded, and thus agree with Dr. Quested, that Americans are still confused about Central Asia since the breakup of the Soviet Union and may be waiting for everything to get a little more settled in that region before investing time and energy in figuring governments, etc all out. Therefore, the old wall maps from American elementary school classrooms may. until that time, continue to rigidly exist in the minds of many, and Mongolia will stay somewhere above China and beyond the Great Wall as a salmon pink-colored country that is surrounded by other countries in different hues and looks, according to the longitude and latitude, very, very cold.

One of the most current surprises about the lack of knowledge concerning Mongolia that echoes Dr. Quests perspective occurred at an international conference in the summer of 1996 when a presenter continually referred to Inner Mongolia (a Chinese term) as an integral part of the new independent nation of Mongolia, without any distinction between this northern part of Chin? That is filled with Mongolians and the new democratic republic that was referred to as "somewhere out there"". 


\section{To Begin}

Possibly the most disheartening words for me in Dr. Quester's paper were "American is not really interested in discovering new ethnic complexities in that (Central Asia) area."As stated based on my informal poll, I agree in concept.

However, I am compelled to humbly represent the Americans (and I admit there may be only a few of us) who are greatly interested in Mongolia because of our specific academic background and interest. For example, my own particular research interest continues to be the cultural transmission of values by both parents and schools and participatory research that "fosters social and political integration of peoples" (McGuinn, p 342).

Another area of investigation for me is how multicultural, intercultural and global education processes connect. I find it fascinating that after their previous history of being both dominator and dominated, Mongolians have chosen to actively seek guidance for their new government so it will actively reflect democratic principles. Philosophically, there is much to study within this process. Educational policy for Mongolia is an unexplored area in Dr.Quester's discussion of potential policy avenues and analysis. I must leave any political analysis of this process to those more trained in the field as is Dr.Quester. However, as an educational researcher, seeking to find meaning and metaphor in the new democracy of Mongolia becomes an exciting part of an examination of the education of their children and the transmission of cultural values to their next generation.

- During my most resent trip to Ulaan Baatar during the fall of 1996, I was able to talk with Mongolian educators and government officials who shared an intense involvement in the education and well being of the children of Mongolia. TheDiscussions all have strong possibilities for potential future collaboration. These following areas of research and continued dialogue serve as an example of what is possible:

- Studies of the transmission of cultural values through art.

Based on observation and discussions at the international children's art exhibition at the Children's Palace in Ulaanbaatar

- Participatory research within community-based sources of learning and collaborative research opportunities.

Based on meetings with the Director of the

National Child Study Center

- Analysis of the support of the Mongolian government for innovative approaches to the education of their children that reflects John Dew's concept 
of building a nation of democratically educated communities. Based on meetings with an official in the Ministry of Education, responsible for early childhood education

- keen interest in the development of connections dinosaur study for young children in both Mongolia and the United States, Based on a discussion with my friend Dr.Perle. Chair of the Geology Department at Mongolian National University and former Director of the Natural History Museum in Ulaanbaatar.

\section{Suggestions}

Dr.Quester states, "It is to everyone's interest to encourage Americans to visit Mongolia, and to get to know more about the country (p.74)". Based on my own continued experiences in Mongolia, I offer the following suggestions for gathering information about Mongolia as a mutually valuable experience:

1. Collaboration in authentic experiences and research that would support democratic participation.

2. Encouragement of scholarly activities in specific areas that are of mutual benefit.

3. Commitment by interested American to educate and share information about Mongolia in the United States.

Additionally, it is important to be mindful of the imperatives for educators offered by McQuinn (1996) for contemporary international comparative researchers:

- "People worldwide are demanding a voice in the decisions that affect their lives. They want democracy in their relationships, in their families, in their communities, in their places of work, and in their governments", (p. 355)

- "[research] should seek to increase democratic participation among all peoples, (p. 356)

- Research on education and democratization clearly demonstrates that democratic engagement in adult life is the result of having participated as a youth.”(p.356)

\section{Conclusion}

Improved understanding and identification between the United States and Mongolia goes beyond an analysis of the mega policies between China and Mongolia and the U.S. and Mongolia. Filler understanding needs to include what is happening within the infrastructure of Mongolia and its people for me, 
this involves the daily communication and transmission of values for Mongolians and their children.

Democracy has been defined as " "an open system that is best possible to respond to people's basic needs-that is, as a set of possibilities that continually must be sought, redefined and brought into being" (McGuinn, 1996). There are many wonderful opportunities in Mongolia for Americans-but not, of course, with the goal of making Mongolia a United States clones. Rather, I believe the opportunities are here for Americans to actively engage our hard-earned experiential know ledge and theory concerning self-determination and empowennent from over two hundred years of practicing our own experiment in a democratic process in our daily lives, both as individuals and members of a community.

As Dr.Quester states in his final analysis, a mutual patience is needed for the process of Mongolia's independence, “...this is a matter for decades or centuries rather than quick solutions." Often Americans want a quick fix or fast product. Instead, I hope that we can learn together what democracy is all about for the first time or once again within a growing, evolving and authentic friendship with Mongolia.

In closing, I am reminded of the government official in Ulaanbaatar who told me, "We don't mind people coming in to help us and conduct research; but we also want to learn from their research, so we can help ourselves. That more than often is not the case." I only hope, after all these years of talking, that we, as Americans, can help in strength and learn from this country's "rediscovery of national identity and process of nation building" (Batbayar, p.4. The Mongolian Journal of International Affairs, no. 3, and 1996) and that the Mongolians can grow in strength and teach us patience and a slept-determined model of friendship.

\section{Bibliography}

Dewey, J. (1916) Democracy and education: an introduction to the philosophy of education. New York: Macmillan.

McGuinn, N.F. (1996). Education, Democratization and Globalization: A Challenge for Comparative Education. Comparative Education Review, 4, 341357.

Quested, G.H. (1996). American sensitivity toward Mongolia. The Mongolian Journal of International Affairs, 3, 68-76. 